\title{
Ambient and biological monitoring of cokeoven workers: determinants of the internal dose of polycyclic aromatic hydrocarbons
}

\author{
F J Jongeneelen, Flora E van Leeuwen, S Oosterink, R B M Anzion, \\ $F$ van der Loop, R P Bos, H G van Veen
}

\begin{abstract}
Polycyclic aromatic hydrocarbons (PAH) were measured in the breathing zone air of 56 battery workers at two cokeovens during three consecutive days. The concentration of total PAH ranged up to $186 \mu \mathrm{g} / \mathrm{m}^{3}$. The concentration of pyrene ranged up to $24 \mu \mathrm{g} / \mathrm{m}^{3}$. Preshift and end of shift urine samples were collected to determine 1-hydroxypyrene, a metabolite of pyrene. Control urine samples were available from 44 workers in the shipping yard of a hot rolling mill. The median values of $1-$ hydroxypyrene in urine of smoking and non-smoking controls were 0.51 and $0.17 \mu \mathrm{mol} / \mathrm{mol}$ creatinine, respectively. Concentrations of 1-hydroxypyrene up to $11.2 \mu \mathrm{mol} / \mathrm{mol}$ were found in the urine of the cokeoven workers. At the start of the three day working period after 32 hours off work, the 1-hydroxypyrene concentrations were four times higher and at the end of the working period 10 times higher compared with control concentrations. Excretion of 1-hydroxypyrene occurred with a half life of 6-35 hours. Both the ambient air monitoring data and the biological monitoring data showed that the topside workers were the heaviest exposed workers. The relation between air monitoring data and biological monitoring data was not strong. Multiple regression analysis was performed to identify determinants of the internal dose. The combination of exposure and smoking amplify each other and the use of a protective airstream helmet decreases the internal dose. An effect of alcohol consumption and the use of medication on the toxicokinetics of pyrene was not found.
\end{abstract}

Department of Toxicology, University of Nijmegen, PO Box 9101, 6500 HB Nijmegen, The Netherlands

F J Jongeneelen, R B M Anzion, F van der Loop, R P Bos Netherlands Cancer Institute, 1066 CX Amsterdam $F$ E van Leeuwen

Department of Occupational Health and Safety, Hoogoven Groep BV, PO Box 10000, 1970 CA IJmuiden

S Oosterink, H G van Veen
In coke works large amounts of tar fumes, containing polycyclic aromatic hydrocarbons (PAH), are released from the ovens in which coal is pyrolysed into coke. Thus battery workers in the vicinity of the ovens are highly exposed to PAH. The workers at the top of the battery (top side workers) belong to the highest exposed group. ${ }^{1}$ The death rate from respiratory cancers for workers dealing with coal carbonisation is significantly increased ${ }^{2-7}$ and other types of cancers associated with exposure to $\mathrm{PAH}$ are also increased.

The application of biological monitoring techniques to evaluate workers' exposure may contribute significantly to risk assessment by allowing the estimation of the effectively absorbed dose rather than just the external exposure concentrations as evaluated by environmental monitoring techniques.

Increased urinary concentrations of 1-hydroxypyrene were found in workers exposed to $\mathrm{PAH}-$ for example, among workers exposed to the wood preservative creosote oil, ${ }^{89}$ coal tar distillary workers, ${ }^{10}$ road paving workers using tar blended binders, ${ }^{11}$ and petroleum coke workers. ${ }^{12}$ The most intense phenolic peak in a GC-MS-chromatogram of cokeoven workers' urine corresponds to 1-hydroxypyrene (G Grimmer et al, 11th international symposium on polynuclear aromatic hydrocarbons, Gaithersbrag, 1987). This metabolite of pyrene has been suggested as a suitable biological indicator of the internal dose of PAH. ${ }^{9}$

We present data on the concentrations of PAH in breathing zone air and 1-hydroxypyrene in urine (hpU) of cokeoven workers. Job category at the cokeoven, breathing zone air concentrations, hours of exposure, protective devices, and personal variables are studied as determinants of the internal dose.

\section{Study design, subjects, and methods}

\section{STUDY DESIGN}

Fifty six men at two cokeovens of a steel plant who worked as battery workers volunteered to participate in this study. Personal air samples of the workers were taken during the three consecutive morning shifts (0600-1400) in November/December 1986. The air samples were taken during the hours of work 
at the cokeoven (=exposure hours). The daily exposure hours and job activities were carefully registered by several industrial hygienists. The three day sampling period was preceded and followed by a workfree period of 32 hours.

On the same three days, spot urine samples just before (preshift $=0600$ ) and immediately after the shift (end of shift $=1400$ ) were collected. The 44 workers from the shipping yard at the hot rolling mill who were chosen as the control group collected one spot urine sample at the end of shift (1400). Blood samples of workers and controls were collected at the end of the third shift.

The workers at the two cokeovens were classified by an occupational hygienist into five job categories as follows:

Job category $A=$ workers of coke side of oven 1

Job category $B=$ workers of topside oven 1

Job category $C=$ workers of push side of oven 2

Job category $\mathrm{D}=$ workers of maintenance oven 2

Job category $\mathrm{E}=$ workers of topside oven 2 .

Interviews were conducted by a trained interviewer using a questionnaire about personal characteristics including ethnic origin, smoking habits, alcohol consumption, use of medication, and the use of protective devices at work, especially airstream helmets (type AH1, RACAL Safety Ltd).

\section{SUBJECTS}

Table 1 lists the personal characteristics of the cokeoven workers and controls (age, smoking habits, ethnic origin). The distribution of age and smoking habits of exposed workers and controls were similar but most of the cokeoven workers were from abroad, whereas the controls were mostly Dutch.

\section{AIR SAMPLING}

During the hours of work on the battery, personal samples of airborne particulates were collected on a $37 \mathrm{~mm}$ Teflon filter (pore size $1.2 \mu \mathrm{m}$ ) using samplers, which were designed according to ISO/TC $146 .{ }^{13}$ The sampler was equipped with a cone over the face. When used in conjunction with a suction flow of $31 / \mathrm{min}$, a suction velocity of $1.25 \mathrm{~m} / \mathrm{s}$ was reached in the face entrance of the sampler, according to the recommendations of the Staubforschungsinstitut

Table 1 Personal data of the workers

\begin{tabular}{lrrrrrrr}
\hline & \multicolumn{6}{c}{ Cokeoven workers job category } \\
\cline { 2 - 6 } & $A$ & $B$ & $C$ & $D$ & $E$ & \multirow{2}{*}{ Controls } \\
\hline No & 7 & 20 & 7 & 11 & 9 & 44 \\
Age (AM) & 37 & 33 & 33 & 37 & 39 & 34 \\
Smoking (\%) & 57 & 55 & 29 & 64 & 56 & 66 \\
Ethnic origin (\%) & 71 & 50 & 72 & 91 & 89 & 16 \\
\hline
\end{tabular}

$\star 0$ Foreign workers.

$\mathrm{AM}=$ Arithmetic mean.
(FRG) ${ }^{14}$ After sampling the filters were stored in the dark at $-20^{\circ} \mathrm{C}$. The samples were analysed within three weeks.

\section{DETERMINATION OF PAH}

The filters were extracted ultrasonically with toluene $(1 \mathrm{ml})$ for 30 minutes. The non-dissolved particles were removed by centrifugation.

PAH analyses were conducted on capillary GLC with FID (column CP Sil $8 \mathrm{CB}, 0.32 \mathrm{~mm}$ internal diameter, film thickness $0.11 \mu \mathrm{m}$ ). The air samples were analysed for 11 different PAH. The selected compounds included PAH with three, four, five, and six aromatic rings-namely, phenanthrene, anthracene, fluoranthene, pyréne, benz(a)anthracene, chrysene, ben $z(b+j+k)$ fluoranthene, benzo(e)pyrene, benzo(a)pyrene, indeno(1,2,3c,d)pyrene, and benz(ghi)perylene. The detection limit of pyrene was $0.6 \mu \mathrm{g} / \mathrm{m}^{3}$, total PAH $1.0 \mu \mathrm{g} / \mathrm{m}^{3}$.

\section{1-HYDROXYPYRENE IN URINE}

Urine samples were stored at $-20^{\circ} \mathrm{C}$. Metabolites in urine were deconjugated by enzymic hydrolysis and a solid phase sample clean up was applied. HPLC analysis allowed the determination of the sum of free and conjugated 1-hydroxypyrene in urine at the nmol/l level. A full description of the method is presented elsewhere. ${ }^{15}$ Urinary 1-hydroxypyrene concentrations were corrected for creatinine. Correction with low or high creatinine values are not reliable. Therefore, urine samples with a creatinine content outside the range of $4-34 \mathrm{mmol} / \mathrm{l}$ were excluded for the analysis of data.

\section{1-HYDROXYPYRENE IN BLOOD}

Peripheral blood samples $(50 \mathrm{ml})$ were withdrawn by venepuncture into tubes containing EDTA. Total white cell counts were collected by centrifugation after incubation with $0.12 \mathrm{M} \mathrm{NH}_{4} \mathrm{Cl}$ to lyse the red blood cells. DNA was isolated to determine benzo(a)pyrene-DNA adducts. Detailed results about DNA adduct monitoring will be published elsewhere (FJ van Schooten, et al).

After centrifugation the blood plasma was stored at $-20^{\circ} \mathrm{C}$. Plasma $(2 \mathrm{ml})$ was diluted with $0 \cdot 1 \mathrm{~N}$ acetate buffer $(5 \mathrm{ml}, \mathrm{pH}=5)$ and mixed with a vortex. A Seppak-C18 cartridge (Waters, Milford, MA, USA) was used to separate 1-hydroxypyrene from the plasma. After priming the cartridge, the sample was loaded, washed ( $10 \mathrm{ml}$ aqua dust), and the retained metabolite was eluted using $9 \mathrm{ml}$ methanol. The solvent was evaporated under a gentle flow of nitrogen $\left(40^{\circ} \mathrm{C}\right)$ and the residue dissolved in $0.5 \mathrm{ml}$ methanol. The samples were analysed with HPLC, equal to the methanolic urine sample. The recovery (SD) of the 1-hydroxypyrene from plasma was $87(18) \%, \mathrm{n}=7$. Detection limit was $0.5 \mathrm{pmol} / \mathrm{ml}$ plasma. 
Table 2 Mean exposure of the individual cokeoven workers over three shifts ${ }^{\star}$

\begin{tabular}{|c|c|c|c|c|c|}
\hline & \multicolumn{5}{|l|}{ Job category } \\
\hline & $A(n=5)$ & $B(n=20)$ & $C(n=7)$ & $D(n=10)$ & $E(n=9)$ \\
\hline $\begin{array}{l}\text { Daily exposure }(\mathrm{h}) \\
\text { AM (range) } \\
\text { Total PAH } \dagger\left(\mu \mathrm{g} / \mathrm{m}^{3}\right) \\
\text { GM (range) } \\
\text { Pyrene }\left(\mu \mathrm{g} / \mathrm{m}^{3}\right) \\
\mathrm{GM}(\text { range })\end{array}$ & $\begin{array}{l}5 \cdot 7 \\
(5 \cdot 2-6 \cdot 7) \\
6 \cdot 9 \\
(<1-46) \\
<0 \cdot 6 \\
(<0 \cdot 6-4 \cdot 8)\end{array}$ & $\begin{array}{l}5 \cdot 3 \\
(2 \cdot 6-6 \cdot 2) \\
17 \cdot 0 \\
(7 \cdot 3-39) \\
2 \cdot 0 \\
(<0 \cdot 6-4 \cdot 4)\end{array}$ & $\begin{array}{l}3 \cdot 8 \\
(2 \cdot 9-4 \cdot 7) \\
13 \cdot 9 \\
(3 \cdot 6-77) \\
1 \cdot 6 \\
(<0 \cdot 6-9 \cdot 8)\end{array}$ & $\begin{array}{l}3 \cdot 3 \\
(2 \cdot 4-4 \cdot 9) \\
13 \cdot 6 \\
(<1-43) \\
1 \cdot 8 \\
(<0 \cdot 6-6 \cdot 1)\end{array}$ & $\begin{array}{c}4 \cdot 0 \\
(3 \cdot 5-4 \cdot 8) \\
12 \cdot 9 \\
(1 \cdot 8-37) \\
1 \cdot 7 \\
(1 \cdot 8-7 \cdot 3)\end{array}$ \\
\hline
\end{tabular}

* Mean of three or fewer observations per worker.

+Sum of 13 PAH.

AM $=$ Arithmetic mean

GM = Geometric mean.

\section{STATISTICAL ANALYSIS}

The strength of determinants of exposure was investigated with the average value of the exposure variables of three days (preshift $h p U$, end of shift $\mathrm{hpU}$, pyrene in air, and hours of exposure) of each cokeoven worker. Data of the exposure were presented with the geometric mean (GM) being more representative of a skewed distribution of data than the arithmetic mean (AM). Correlation was calculated using the non-parametric Spearman correlation test. Multiple analysis of variance (ANOVA) or multiple linear regression analysis (GLM) were performed with the SAS computer software package. The $p$ value of the test ( $t$ test, Mann-Whitney $U$ test, $F$ test) is given. Owing to missing data, the number of workers engaged in each analysis varies.

\section{Results}

AIR MONITORING

The total PAH concentration in breathing zone air of the cokeoven workers ranged up to $186 \mu \mathrm{g} / \mathrm{m}^{3}$. The concentration of pyrene ranged up to $24 \mu \mathrm{g} / \mathrm{m}^{3}$.
Table 2 shows the mean exposure of the individual cokeoven workers over three shifts to total PAH, iv pyrene, and the daily exposure period. The data are presented for each of the five job categories. The highest PAH concentrations and pyrene concentrations were found among the top side workers of cokeoven 1 (job category B).

The relation between the pyrene concentration and total PAH concentration was calculated with the mean of the three determinations per worker. Figure 1 shows a graph of pyrene versus total PAH. The agreement between pyrene and total PAH is high $(r=0.88)$, indicating that pyrene is an appropriate indicator for exposure to PAH at cokeovens. The relative distribution of PAH (PAH profile) in the personal air samples (fig 2) shows that fluoranthene and benz(a)anthracene were the most abundant PAH.

The intraindividual variability of the exposure was large. The average coefficient of variation (CV) of the pyrene concentration between three shifts of 47 workers was $68 \%$.
Figure 1 Relation between total $P A H$ and pyrene concentration in breathing zone of cokeoven workers. Points represent a three day average of individuals. Regression line is indicated.

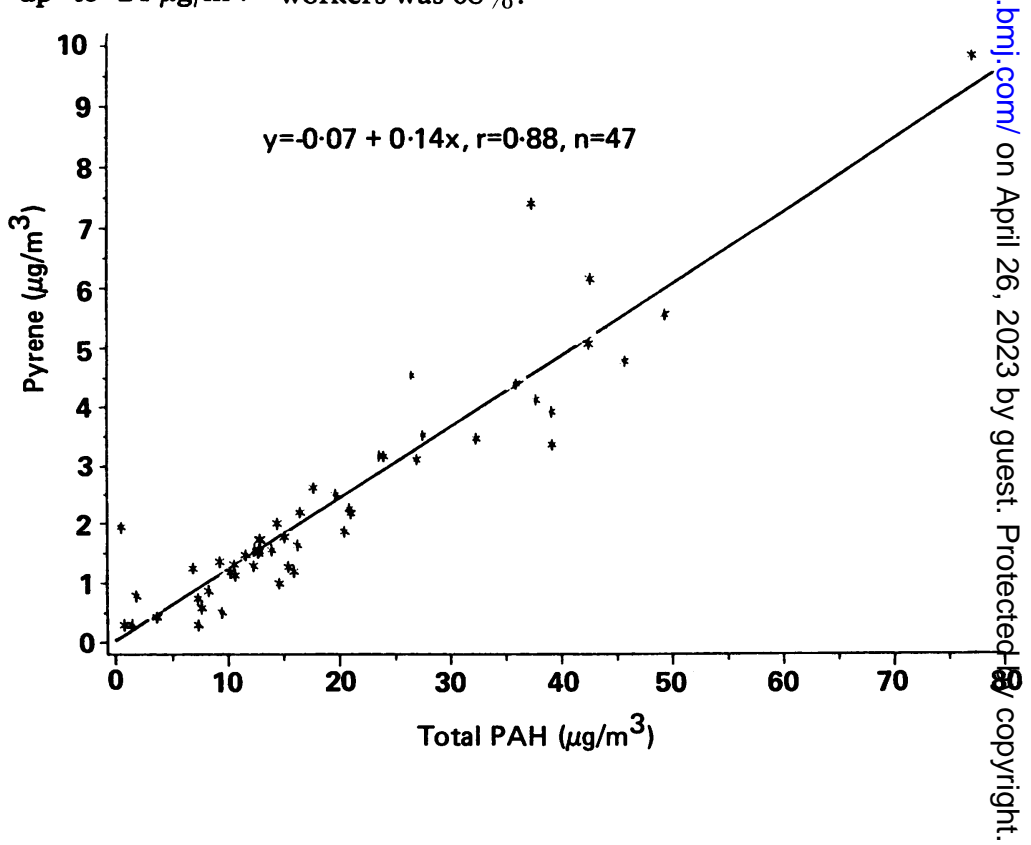




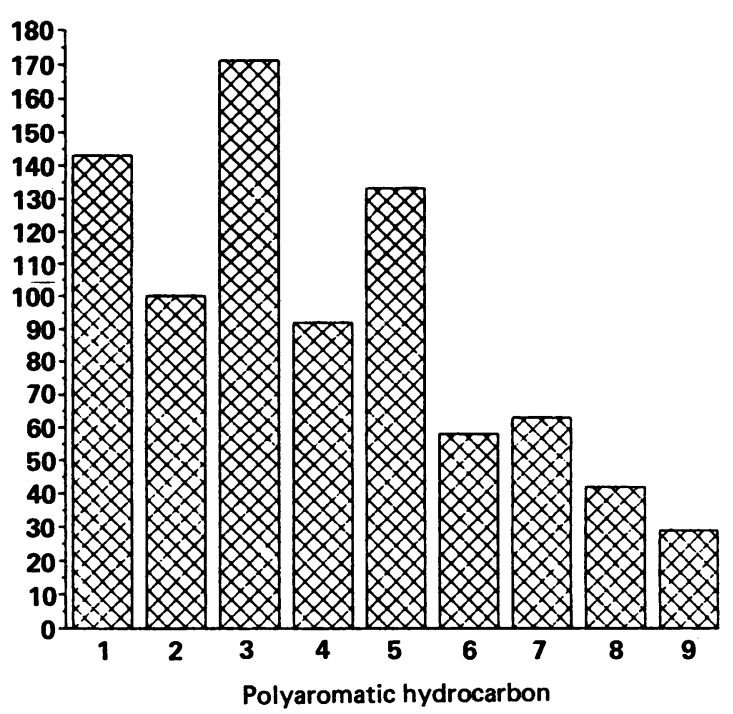

Figure 2 Average PAH-profile of personal air samples of 54 cokeoven workers, three measurements each. Pyrene concentration is taken as $100 \% .1$ = fluoranthene,

$2=$ pyrene, $3=$ benz $(a)$ anthracene, $4=$ chrysene,

$5=$ benz $(b+j+k)$ fluoranthene, $6=$ benzo $(e)$ pyrene,

$7=$ benzo $(a)$ pyrene, $8=$ indeno $(1,2,3-c, d)$ pyrene,

$9=$ benz $($ ghi $)$ perylene.

\section{1-HYDROXYPYRENE IN URINE}

The smoking control workers showed a higher level of urinary 1-hydroxypyrene compared with nonsmoking controls (GM(5th-95th percentile $)=0.51(0.04-1.24) \quad \mathrm{n}=28$ and $0 \cdot 17(0.01-$ $0.93) \mu \mathrm{mol} / \mathrm{mol}$ creatinine, $\mathrm{n}=14$, respectively). The difference was statistically significant (MannWitney $U$ test, $p=0.003$ ). Table 3 shows hpU-

Table 3 1-Hydroxypyrene of controls ${ }^{\star}$ by class of smoking habits ( $\mu \mathrm{mol} / \mathrm{mol}$ creatinine)

\begin{tabular}{lrll}
\hline Class (cig/day) & No & $G M$ & (Range) \\
\hline 0 & 14 & $0 \cdot 17$ & {$[$ nd-0.93] } \\
$1-10$ & 6 & $0 \cdot 26$ & {$[0 \cdot 18-0 \cdot 59]$} \\
$11-20$ & 13 & 0.52 & {$[0.07-1 \cdot 37]$} \\
$>20$ & 6 & 0.62 & {$[0.07-1 \cdot 09]$} \\
\hline
\end{tabular}

*Three smokers could not be classified. levels for four classes of smoking habits in controls. A dose effect relation is shown for increasing hpU with increasing number of cigarettes a day.

Table 4 shows the hpU levels in the preshift and the end of shift samples of the cokeoven workers. Obviously the urinary metabolite concentrations among cokeoven workers are largely increased compared with controls. An increase of hpU over the shift was found. In table 4 the workers are classified according to smoking status. The mean difference in hpU between smokers and non-smokers of the cokeoven group $(0.90 \mu \mathrm{mol} / \mathrm{mol})$ was higher than the difference found in the control group $(0.34 \mu \mathrm{mol} /$ mol), suggesting a more than additive effect of exposure and smoking on the body burden.

Table 5 shows three day average hpU of the workers classified by job category. The topside workers of cokeoven 1 (job category B) showed the highest end of shift hpU levels and the highest increase over the shift (end of shift minus preshift value). This agrees with the air monitoring data, which also show the topside workers of cokeoven 1 to be the highest exposed workers.

The workers were interviewed about their habit of using an airstream helmet during shift hours (always, sometimes, never). The workers who sometimes wore an airstream helmet could not be classified and were not involved in a comparison. Table 6 shows the three day average hpU of workers always using an airstream helmet and the average of workers never using such a helmet. The highest hpU levels were found among the non-users. A multiple linear regression analysis was performed with end of shift 1hydroxypyrene concentrations as the dependent variable and with the following independent variables: preshift hpU, pyrene in air, hours of exposure, smoking habits (yes/no), and use of airstream helmet (never/always). For end of shift hpU, preshift hpU, pyrene in air, and hours of exposure, the average of three days was taken. The preshift hpU, smoking habits, and the use of an airstream helmet appeared to be significant predictors for end of shift hpU (table 7). Neither the concentration in ambient air of pyrene nor the duration of the exposure significantly contributed to the 1-hydroxypyrene concentration at the end of the shift. This is remarkable, because pyrene is

Table 4 1-Hydroxypyrene in urine ${ }^{\star}$ of smoking and non-smoking cokeoven workers ( $\mu$ mol/mol creatinine)

\begin{tabular}{|c|c|c|c|c|c|c|}
\hline & \multicolumn{2}{|l|}{ Day 1} & \multicolumn{2}{|l|}{ Day 2} & \multicolumn{2}{|l|}{ Day 3} \\
\hline & Preshift & End of shift & Preshift & End of shift & Preshift & End of shift \\
\hline $\begin{array}{l}\text { Smoking } \\
\text { Cokeoven } \\
\text { Workers }\end{array}$ & $\begin{array}{l}0.98 \\
(0 \cdot 26-3 \cdot 5) \\
25\end{array}$ & $\begin{array}{l}3 \cdot 0 \\
(0 \cdot 46-11 \cdot 2) \\
25\end{array}$ & $\begin{array}{l}1 \cdot 31 \\
(\text { nd }-4 \cdot 1) \\
30\end{array}$ & $\begin{array}{l}2 \cdot 75 \\
(0 \cdot 41-10 \cdot 1) \\
30\end{array}$ & $\begin{array}{l}1 \cdot 36 \\
(0 \cdot 23-4 \cdot 7) \\
26\end{array}$ & $\begin{array}{l}3 \cdot 37 \\
(0 \cdot 58-7 \cdot 3) \\
25\end{array}$ \\
\hline $\begin{array}{l}\text { Non-smoking } \\
\text { Cokeoven } \\
\text { Workers }\end{array}$ & $\begin{array}{l}0 \cdot 77 \\
(0 \cdot 24-1 \cdot 7) \\
19\end{array}$ & $\begin{array}{l}1 \cdot 78 \\
(0 \cdot 70-3 \cdot 9) \\
19\end{array}$ & $\begin{array}{l}1 \cdot 23 \\
(0 \cdot 24-3 \cdot 3) \\
22\end{array}$ & $\begin{array}{l}1.75 \\
(0.36-6 \cdot 9) \\
23\end{array}$ & $\begin{array}{l}1 \cdot 28 \\
(0.56-2 \cdot 5) \\
22\end{array}$ & $\begin{array}{l}1.92 \\
(0 \cdot 39-11 \cdot 2)\end{array}$ \\
\hline
\end{tabular}

^GM (range) and number of observations. 
Table 5 1-Hydroxypyrene in urine (three day average) of cokeoven workers by job category ( $\mu$ mol/mol creatinine)

\begin{tabular}{|c|c|c|c|c|c|}
\hline & \multicolumn{5}{|l|}{ Job category } \\
\hline & $A(n=7)$ & $B(n=19)$ & $C(n=7)$ & $D(n=11)$ & $E(n=9)$ \\
\hline $\begin{array}{l}\text { End of shift } \\
\text { Increase over shift }\end{array}$ & $\begin{array}{l}2 \cdot 0 \\
(0 \cdot 7-2 \cdot 6) \\
0 \cdot 13 \\
(-1 \cdot 2-1 \cdot 5)\end{array}$ & $\begin{array}{l}3 \cdot 3 \\
(0 \cdot 8-7 \cdot 5) \\
2 \cdot 00 \\
(0-4 \cdot 9)\end{array}$ & $\begin{array}{l}1.9 \\
(0 \cdot 6-3 \cdot 5) \\
0 \cdot 67 \\
(-0 \cdot 4-2 \cdot 0)\end{array}$ & $\begin{array}{l}1.9 \\
(1.31-4 \cdot 1) \\
1.2 \\
(0 \cdot 33-3 \cdot 0)\end{array}$ & $\begin{array}{l}2 \cdot 7 \\
(1 \cdot 3-6 \cdot 5) \\
1 \cdot 3 \\
(-1 \cdot 3-4 \cdot 6)\end{array}$ \\
\hline
\end{tabular}

${ }^{*} \mathrm{GM}$ (range) of the mean of three or fewer observations per worker.

the only known parent compound of 1-hydroxypyrene.

RELATION OF INHALED PYRENE DOSE VERSUS EXCRETION OF 1-HYDROXYPYRENE IN URINE The correlation between the "pyrene in air ${ }^{\star}$ exposure hours" and end of shift hpU became stronger over the three shifts: the Spearman correlation coefficient, number of observations, and significance level of the three shifts were:

shift 1: $r_{\mathrm{s}}=0.15, \mathrm{n}=43, \mathrm{p}=0.33$

shift 2: $r_{s}=0.28, n=52, p=0.04$

shift 3: $r_{s}=0 \cdot 40, n=45, p=0.006$

The correlation coefficients between "pyrene in air exposure hours" and the "pre-shift next day hpU" were:

"exposure shift 1" versus "preshift 2 hpU": $r_{\mathrm{s}}=0 \cdot 11, \mathrm{n}=45, \mathrm{p}=0.45$

"exposure shift 2 " versus "preshift 3 hpU": $r_{s}=0.35, n=46, p=0.02$

One reason for the increase of correlation in the course of the three shifts might be that the response of the body to the absorption of pyrene is rather slow.

Table 6 1-Hydroxypyrene in urine ${ }^{\star}$ of cokeoven workers never or always using an airstream helmet ( $\mu \mathrm{mol} / \mathrm{mol}$ creatinine)

\begin{tabular}{llll}
\hline Class & No & $\begin{array}{l}\text { End of shift } \\
G M \text { (range) }\end{array}$ & $\begin{array}{l}\text { Increase over shift } \\
\text { GM(range) }\end{array}$ \\
\hline Never & 14 & $3 \cdot 0(0 \cdot 8-7 \cdot 3)$ & $1 \cdot 9(-1 \cdot 2-4 \cdot 2)$ \\
Always & 29 & $1 \cdot 7(0 \cdot 6-4 \cdot 1)$ & $0.8(-1 \cdot 3-3 \cdot 0)$ \\
\hline
\end{tabular}

${ }^{\star} \mathrm{GM}$ (range) of the mean of three or fewer observations per worker.

Table 7 Multiple regression analysis ${ }^{\star}$ for end of shift $h p U \dagger$ of cokeover workers

\begin{tabular}{lcl}
\hline & $\begin{array}{l}\text { Regression } \\
\text { coefficient }(S E)\end{array}$ & $p$ Value \\
\hline Preshift hpU $\dagger(\mu \mathrm{mol} / \mathrm{mol})$ & $0.86(0.28)$ & 0.004 \\
Pyrene in air $\left(\mu \mathrm{g} / \mathrm{m}^{3}\right)$ & $0.14(0.11)$ & 0.21 \\
Exposure hours $\dagger(\mathrm{h} /$ day $)$ & $-0.13(0.23)$ & 0.57 \\
Airstream helmet $(0=$ always, & $0.99(0.49)$ & 0.05 \\
$\quad 1=$ never $)$ & $0.71(0.39)$ & 0.08 \\
Smoking habits $(0=$ no, $1=$ yes $)$ & $1.92(1.16)$ & \\
Intercept (SE) & \\
\hline
\end{tabular}

$\star R^{2}=0.44, n=42$.

$\dagger$ Three day average.
When studying the relation external exposure versus uptake of a compound with a moderate half life, the fraction of the inhaled dose excreted in urine over a period of consecutive shifts may be used as a variable for the study of the individual differences of $V$ the kinetics in workers. Borm et al used this approach of to study skin absorption of dimethylacetamide. ${ }^{16}$ The formula for pyrene exposure:

$F=\frac{\left[(\text { AUC-background })^{\star} \text { creatinine }\right]}{\left(C^{\star} t^{\star} V\right) / M}$ (formula 1$)$

with:

F = Calculated fraction of inhaled pyrene excreted in urine as 1-hydroxypyrene

AUC-background = Area under concentration time curve minus the area of under baseline of controls $((\mu \mathrm{mol} /$ mol creat $)^{\star} \mathrm{t}$ )

creat $=$ Creatinine excretion $(\mathrm{mol} / \mathrm{h})$

$\mathrm{C}=$ Concentration pyrene in $\operatorname{air}\left(\mu \mathrm{g} / \mathrm{m}^{3}\right)$

$\mathrm{t}=$ Daily exposure hours $(\mathrm{h})$

$\mathrm{V}=$ Ventilation rate $\left(\mathrm{m}^{3} / \mathrm{h}\right)$

$M=$ Molecular weight

The inhaled pyrene dose during three shifts was calculated with the assumptions of a ventilation rate (V) of $17 \mathrm{l} / \mathrm{min}$ and a retention of $100 \%$. The excretion of 1-hydroxypyrene was calculated by multiplication of the area under curve (AUC) of three days + next 32 hours off work by the total excretion of O creatinine in three days +32 hours (creatinine $\rightarrow$ excretion $=0.016 \mathrm{~mol} / 24 \mathrm{~h}$ ). The preshift $\mathrm{hpU}$ of the next period after 32 hours off work was taken as $N$ the same as the preshift hpU of shift 1 . The data of 34 . workers were available to calculate the fraction $(F)$. $N$ The fraction (F) ranged from 0.1 to 2.2 and fig 3 N shows the frequency distribution of this fraction $(F)$ O and suggests a bimodal distribution of the fraction. Of 34 workers, 10 had a fraction-value $>1$. Knowing that only a part of the body burden of pyrene is $\stackrel{?}{+}$ metabolised to 1-hydroxypyrene $\mathrm{e}^{1718}$ and that the 7 major part is excreted in the faeces, it is surprising that approximately $30 \%$ of the workers have a value $\stackrel{\square}{\square}$ over one. This point is discussed in the next section. $\mathbb{D}$ Analysis of variance of the fraction (F) was carried out for the source's ethnic origin, alcohol consumption, use of medication, smoking habits, and use of 


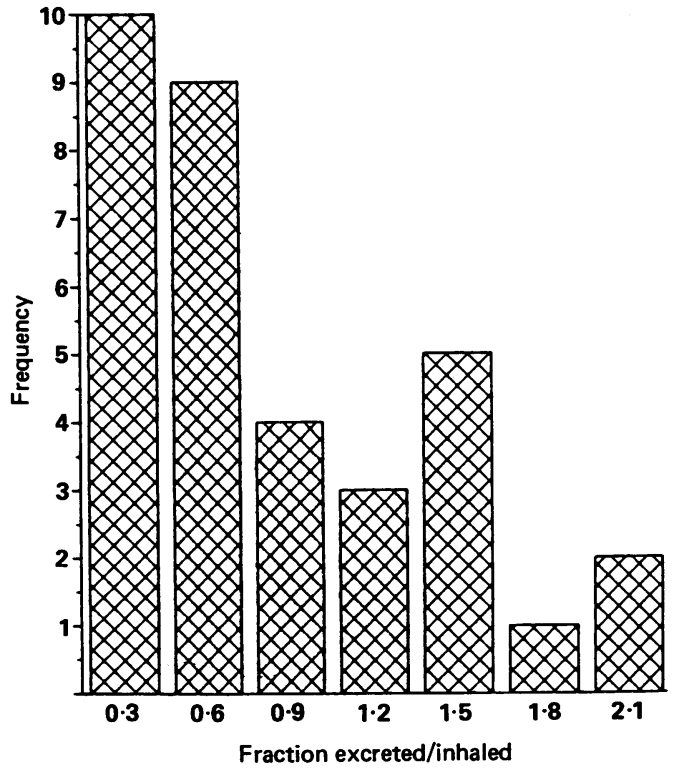

Figure 3 Frequency distribution of calculated fraction of lung dose of pyrene over three days excreted as 1-hydroxypyrene in urine in 34 cokeoven workers.

Table 8 Analysis of variance of the fraction of inhaled pyrene excreted in urine as 1-hydroxypyrene $(n=27)$

\begin{tabular}{lcl}
\hline Source & Fvalue & $p$ \\
\hline Ethnic origin (Dutch/foreign) & 0.50 & 0.49 \\
Consumption of alcohol (yes/no) & 1.11 & 0.31 \\
Use of medication (yes/no) & 0.72 & 0.41 \\
Smoking habits (yes/no) & 0.48 & 0.50 \\
Use of airstream helmet (always/never) & 10.9 & 0.003 \\
\hline
\end{tabular}

airstream helmet. Table 8 shows that only the use of the airstream helmet affected the fraction (F) significantly.

\section{1-HYDROXYPYRENE IN BLOOD}

1-Hydroxypyrene in plasma (hpP) was measured in 46 exposed workers and 43 controls. All plasma concentrations were lower than $7 \mathrm{pmol} / \mathrm{ml}$. The concentration in cokeoven workers did not differ from that of the controls. No relation between the plasma and urine concentrations could be found. Plasma hpP is a poor indicator for pyrene exposure.

\section{ELIMINATION RATE}

The three day monitoring programme included two overnight periods off work (1400-0600). The rate of elimination follows first order kinetics when the rate is directly proportional to the concentration. For each worker the elimination rate constant in the period away from work was calculated assuming first order elimination kinetics.

In formula: $\mathrm{dC} / \mathrm{dt}=-\mathrm{k}_{\mathrm{e}}{ }^{\star} \mathrm{t}$ or in integrated form $\mathrm{C}_{\mathrm{PSnd}}=\mathrm{C}_{\mathrm{ES}} \mathrm{e}^{\mathrm{k}_{\mathrm{e}}{ }^{\star} \mathrm{t}} \quad$ (formula 2) with:

$\mathrm{C}_{\mathrm{ES}}=$ Concentration end of shift $(\mu \mathrm{mol} / \mathrm{mol}$ creat$)$ $\mathrm{C}_{\mathrm{PSnd}}=$ Concentration preshift next day $(\mu \mathrm{mol} / \mathrm{mol}$ creat)

$\mathrm{k}_{\mathrm{e}}=$ Elimination rate constant $\left(\mathrm{h}^{-1}\right)$

$\mathrm{t}=$ Time $(\mathrm{h})$

The mean of the two observations per worker (preshift three minutes postshift two and preshift two minus postshift one) was taken. Because a trace of $\mathrm{hpU}$ may be found in controls, only the data of the workers with significant increased urinary levels were involved in this analysis. Therefore, the data of workers were omitted when the hpU was below the
Figure 4 A plot of elimination rate constant versus end of shift 1-hydroxypyrene in urine of 36 cokeoven workers. Workers with urinary concentrations below 95th percentile of controls were not included. $\square=$ Non-smoking worker, $\odot=$ smoking worker.

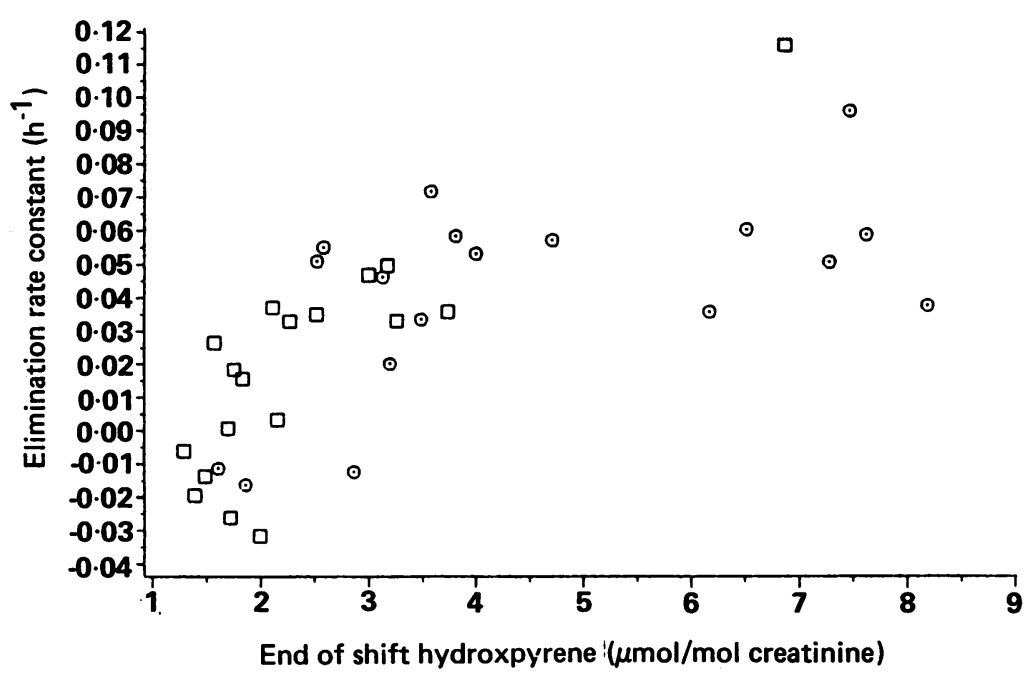


95th percentile of the controls. After this selection, the data of 36 workers were left. Figure 4 shows a plot of the elimination rate constant and end of shift hpU. Of 36 workers, eight showed a negative constant, thus an increase of hpU over the night, probably as a result of a continuing process of absorption in the lungs or skin, or both. Figure 4 shows an increase of the constant $k_{e}$ at relatively low end of shift levels $(<3.0 \mu \mathrm{mol} / \mathrm{mol})$ until a horizontal level, suggesting an initial phase of excretion with first order excretion elimination. Analysis of variance did not show a significant effect of the sources' smoking, alcohol consumption, use of medication, and ethnic origin on the elimination rate constant. When only the workers with high end of shift levels $(>3.0 \mu \mathrm{mol} / \mathrm{mol}$ ) were taken, data of 18 workers were available. The elimination rate constant of this group ranged from $0 \cdot 12$ $0.02 \mathrm{~h}^{-1}$ and the half life $\mathrm{t}_{1}$ (which is by definition in $\left.2 / k_{c}\right)$ ranged from six to 35 hours. The latter values may be considered as the range of the apparent half life of the initial phase of eliminating pyrene.

\section{Discussion}

Air monitoring data generally show high exposure levels of PAH for topside work at cokeovens. ${ }^{161920}$ This report also shows that topside workers are the workers with the highest exposure levels. As the pyrene/total PAH ratio is rather constant in this work environment, biological monitoring by a metabolite of one PAH might be used to study determinants of exposure to total PAH.

A trace amount of 1-hydroxypyrene was found in the urine of non-exposed subjects. This report shows a significant effect of smoking on the hpU level of an industrial control population. This diverges only a little from the results of a previous study, ${ }^{9}$ in which an increase among smoking controls was found but it did not reach significance level $(p<0.05)$. The distribution of smoking habits in the group under investigation and in the previously studied group was similar.

Then difference of hpU between the smoking and non-smoking controls is three times smaller than the difference between the smoking and non-smoking coke workers. This suggests a more than additive effect of exposure and smoking, either due to (1) contamination of cigarettes with tar from the cokeoven, (2) a decreased clearance from the ciliated surface of the upper part of the respiratory system of smokers that will result in an enhanced absorption among exposed smoking workers, or (3) a toxicokinetic effect such as increased resorption or a different metabolic conversion of pyrene in smoking workers. Our data were not extensive enough to test the contribution of each of these reasons.

This report gives evidence on the supposition that wearing an airstream helmet with a built in dust filter decreases the absorption of PAH. The data show a $\stackrel{\mathbb{P}}{\stackrel{8}{2}}$ lower hpU level among the workers who always wear such a helmet. As the regular helmet wearing habits $\stackrel{\vec{F}}{\rightarrow}$ were asked for and not registered daily there might be a bias. Moreover, the workers wearing a protective $\frac{\bar{\partial}}{\bar{D}}$ helmet are most likely to be those with a positive $\frac{\bar{\sigma}}{\partial}$ attitude to clean working conditions. These workers $\stackrel{\mathbb{Q}}{\varrho}$ are expected to follow also other protective measures. क

A previous study suggested biphasic excretion of $\vec{A}$ 1-hydroxypyrene. ${ }^{9}$ This study suggests an excretion with a half life of the initial phase of elimination ranging from six to 34 hours. The affinity of pyrene for lipids and the possibility of its deposition in $\underset{\mathbb{D}}{\triangle}$ adipose tissue is obvious. In our attempts to deter- $\frac{}{3}$ mine 1-hydroxypyrene in plasma we found a rapid $A$ and major disappearance of 1-hydroxypyrene in $V$ plasma, suggesting strong protein binding. The of storage ability in the adipose tissue and the strong $\vec{A}$ binding in plasma might be the cause of the more $\frac{9}{3}$ phasic character of excretion curves. The negative $\overrightarrow{ }$ elimination rate constant of eight out of 36 workers in $\subseteq$ the nights between the shifts may be caused by prolonged exposure after leaving the work environ- $\bar{\varnothing}$ ment, either due to slow resorption of pyrene from the particulate matter in the respiratory tract and from contaminated skin or due to migration from contaminated underwear. ${ }^{21}$

The large range of the fraction $(F)$ of the lung dose found in urine as a metabolite might be explained by three classes of reasons. (1) Endogenous sources of variation might be retained in the respiratory tract, metabolic conversion of pyrene to 1-hydroxypyrene, and deposition in adipose tissue and ratio urinary/ faecal excretion. The in vitro differences in biotransformation capacity of pyrene in human liver preparations are large. ${ }^{22}$ (2) Differences in job categories might induce differences in ventilation rate but might also result in a different dermal exposure. PAH are absorbed through the skin. (3) Personal habits such as smoking, alcohol consumption, or the use of medication might induce alterations in the toxicokin- 을 etics $^{23}$ and thus the fraction (F). Analysis of variance $D$ of the fraction $(F)$ showed no significant effect of smoking, consumption of alcohol, or use of medica- N tion. The large variation of daily exposure levels, the slow resorption process, and the relatively long half $N$ life of elimination might all be responsible to a more $\mathrm{W}$ or less extent for the large range of the fraction $(F)$.

Thirty per cent of the workers had a calculated $O$ fraction value over 1 , thus they excreted more $1-\Phi$ hydroxypyrene in urine than they inhaled pyrene. $\stackrel{?}{+}$ This might be caused either by $(a)$ underestimation $\frac{T}{O}$ of the quantity of inhaled pyrene or by $(b)$ absorption of pyrene through other routes than the respiratory $\stackrel{\mathbb{\Phi}}{\stackrel{\Phi}{\circ}}$ tract. The quantity of inhaled pyrene in airborne $\stackrel{\square}{\square}$ particulate matter was determined but it is known that approximately $50 \%$ of pyrene is present in the 8 gaseous phase in workroom air. ${ }^{192425}$ Therefore, the 
actual inhaled dose of pyrene will have been about two times higher. The quantity excreted metabolite in urine depends on metabolism and excretion routes of pyrene. The importance of the metabolic pathway of pyrene to 1-hydroxypyrene in man has not yet been quantified, although in vitro experiments suggest that 1 -hydroxypyrene is a major metabolite in man. ${ }^{22}$ Taking into account that the retention in the lungs is not $100 \%$ and that the major part of the PAH metabolites is excreted in the faeces, ${ }^{26-28}$ dermal exposure probably constitutes an amount equal to or greater than the respiratory route. A significant relation between pyrene skin exposure and urinary 1hydroxypyrene has already been found among paving workers. ${ }^{11}$

This study showed the effect of the job category at the cokeoven, of smoking habits, and of using protective devices on the body burden of cokeoven workers. A modifying effect of alcohol consumption and the use of medication on the toxicokinetics of pyrene was not established.

Most of the cokeoven workers volunteered to participate in this study and they made it possible to realise this study. The help of many members of the department of Occupational Health and Safety of Hoogovens IJmuiden BV during the field study is gratefully acknowledged. The study was supported by Hoogovens IJmuiden BV and was sponsored by the Ministry of Social Affairs and Employment, Directoraat-Generaal van de Arbeid (DGA), Voorburg, The Netherlands.

1 Lindstedt G, Sollenberg J. Polycyclic aromatic hydrocarbons in the occupational environment. Scand $J$ Work Environ Health 1982;8:1-19.

2 Lloyd WJ. Long-term mortality study of steelworkers: V Respiratory cancer in coke plant workers. J Occup Med 1982;13:53-68.

3 Doll R, Vessey MP, Beasley RWR, et al. Mortality of gas workers-final report of a prospective study. $\mathrm{Br} J$ Ind Med 1972;29:394-406.

4 Sakabe $\mathrm{H}$, Tsuchiya $\mathrm{K}$, Takekura $\mathrm{N}$, et al. Lung cancer among cokeoven workers. Ind Health 1975;13:57-68.

5 Redmond CK, Strobono BR, Cypress RH. Cancer experience among coke by-product workers. Ann NY Acad Sci 1976;271:102-15.

6 International Agency for Research on Cancer. Monographs on the evaluation of the carcinogenic risk of chemicals to humans. Vol 34. Polynuclear aromatic compounds. Part 3. Industrial exposures in aluminium production, coal gasification, coke production and iron steel founding. Lyon: IARC, 1984.

7 Bertrand JP, Chan N, Patris A, et al. Mortality due to respiratory cancers in the cokeoven plants of the Lorraine coalmining industry. $\mathrm{Br} J$ Ind Med 1987;44:559-65.

8 Jongeneelen FJ, Anzion RBM, Leijdekkers C-M, Bos RP, Henderson PT. 1-hydroxypyrene in human urine after exposure to coal tar and a coal tar derived product. Int Arch Occup Environ Health 1985;57:47-55.

9 Jongeneelen FJ, Anzion RBM, Scheepers PTJ, et al. 1Hydroxypyrene in urine as a biological indicator of exposure to polycylic aromatic hydrocarbons in several work environments. Ann Occup Hyg 1988;32:35-43.

10 Jongeneelen FJ, Bos RP, Anzion RBM, Theuvs JLG, Henderson PT. Biological monitoring of polycyclic aromatic hydrocarbons; metabolites in urine. Scand J Work Environ Health 1986;12:137-43.

11 Jongeneelen FJ, Scheepers PTJ, Groenendijk A, et al. Airborne concentrations, skin contamination and urinary metabolite excretion of PAH among paving workers exposed to coal tar derived road tars. Am Ind Hyg Assoc J 1988;49:600-7.

12 Jongeneelen FJ, Anzion RBM, Theuws JLG, Bos RP. Urinary 1 -hydroxypyrene in workers handling petroleum coke. J Toxicol Environ Health 1989;26:133-6.

13 International Standards Organisation (ISO). Size definitions for particle sampling. Am Ind Hyg Assoc J 1985;42:A64-8.

14 Staubforschung Institut. Empfelungen zur Messung und Beurteilung von Gesundheitsgefahrlichen Stauben. (Recommendations for the determinaton of health-damaging particulate matter.) Staub Reinh Luft 1973;3:1-3.

15 Jongeneelen FJ, Anzion RBM, Henderson PT. Determination of hydroxylated polycyclic aromatic hydrocarbons in urine. $J$ Chromatogr 1987;413:227-32.

16 Borm PJA, de Jong L, Vliegen A. Environmental and biological monitoring of workers occupationally exposed to dimethylacetamide. J Occup Med 1987;29:898-903.

17 Harper $\mathrm{KH}$. The metabolism of pyrene. $\mathrm{Br} J$ Cancer 1957;11:499-507.

18 Boyland E, Sims P. Metabolism of polycyclic compounds 23. The metabolism of pyrene in rats and rabbits. Biochem $J$ 1964;90:391-8.

19 Bjorseth A, Bjørseth O, Fieldstadt PE. PAH in the work atmosphere II. Determination in a coke plant. Scand JWork Environ Health 1978;4:224-36.

20 Bjorseth $\mathrm{A}$, Becher $\mathrm{G}$. PAH in work atmospheres: occurrence and determination. Boca Raton: CRC Press, 1986:57-95.

21 Kandus J, Masek V, Jack Z. Determination of the content of benzo(a)pyrene of workers clothes and underclothing in a pitch manufacturing plant. Zentrallblatt Arbeitsmedizin 1972;22:138-41.

22 Jongeneelen FJ. Biological monitoring of occupational exposure to $P A H$. Nijmegen: Scientific Publishers, 1987:31-48. (PhD thesis).

23 Fiserova-Bergerova V. Development of biological exposure indices (BEIs) and their implementation. Appl Ind Hyg 1986;2:87-92.

24 Leinster P, Evans MJ. Factors affecting the sampling of airborne polycyclic aromatic hydrocarbons-a review. Ann Occup Hyg 1986;30:481-95.

25 Lesage J, Perrault G, Durand P. Evaluation of worker exposure to polycyclic aromatic hydrocarbons. Am Ind Hyg Assoc J 1987;48:753-9.

26 Mitchell CE. Distribution and retention of benzo(a)pyrene in rats after inhalation. Toxicol Lett 1982;11:35-42.

27 Sun JD, Wolff RK, Kanapilly GM. Disposition, retention and biological fate of inhaled benzo(a)pyrene absorbed onto ultrafine particles and as a pure aerosol. Toxicol Appl Pharmacol 1982;65:231-44.

28 Grimmer G, Brune H, Dettbarn G, et al. Urinary and faecal excretion of chrysene and chrysene metabolites by rats after oral, intraperitoneal, intratracheal or intrapulmonary application. Arch Toxicol 1988;62:402-5.

Accepted 28 November 1989 